\title{
A case of confusion and bilateral temporal lesions in a young woman
}
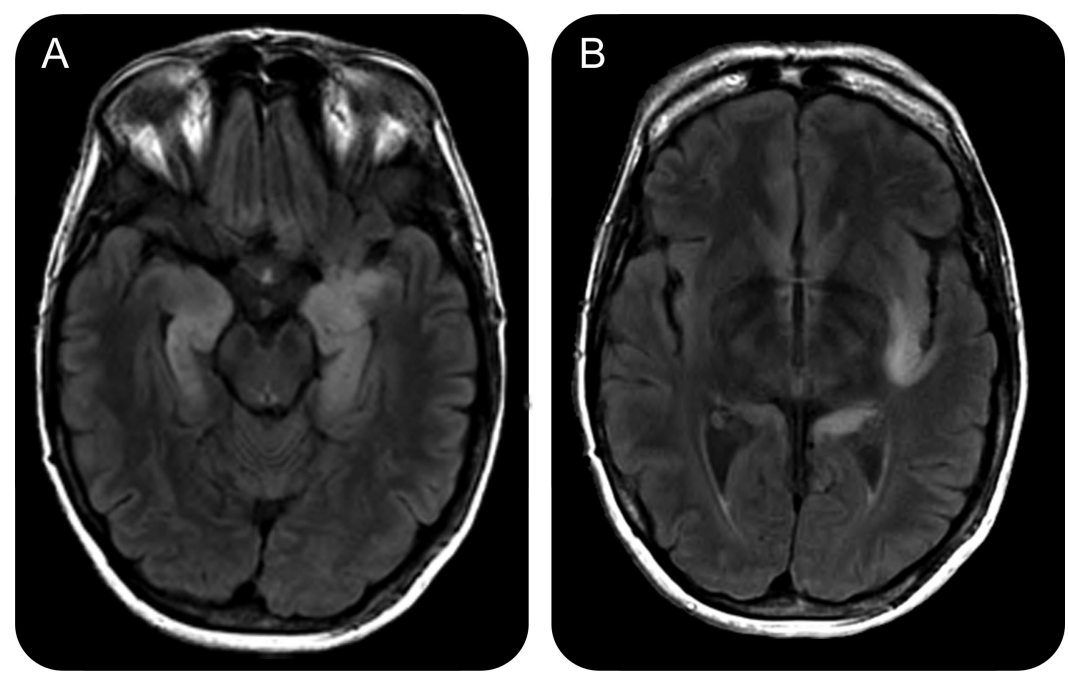

Figure 1 Brain MRI: Diffuse, confluent T2 hyperintensities along bilateral mesial temporal lobes (A); extending into the left insular cortex (B).

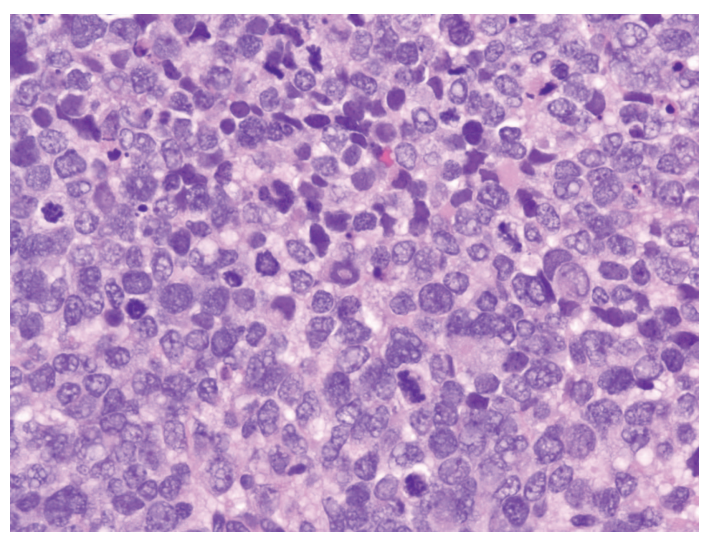

Figure 2 Hematoxylin-eosin stain lymph node biopsy $(60 \times)$ : Large tumor cells $(20-50 \mu \mathrm{m})$ with both salt-and-pepper and vesicular chromatin with robust mitotic activity. Immunohistochemical stains showed diffuse CD-56 and chromogranin positivity with positive TTF-1 staining consistent with lung primary.

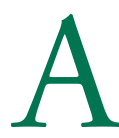

43-year-old right-handed woman with a medical history significant for methamphetamine abuse was admitted after presenting with a rapidly worsening confusion. The patient's family described 3 weeks of progressive disorientation, memory problems, anorexia with weight loss, and bilateral lower extremity neuropathic pain. Her only other pertinent medical history included a 10-pack-year history of tobacco use.

On examination, her vital signs were normal except for a sinus tachycardia. She scored 15/30 on the Mini-Mental State Examination with loss of points primarily on orientation, recall, and attention. There were no abnormalities of her cranial nerves, motor examination, coordination, or gait. Sensory examination demonstrated mild hypoesthesia over her feet, otherwise normal.

Initial laboratory values included a normal complete blood count, complete metabolic panel, and negative rapid plasmin reagin, HIV, and antinuclear antibodies. She had a positive toxicology screen for methamphetamine and a low-normal vitamin B12 level of 282. Her CSF analysis had 4 mononuclear white blood cells, an elevated protein of 142 , normal glucose, and 14 oligoclonal bands present. CSF culture was negative and herpes simplex virus $1 / 2$ and human herpesvirus-6 PCR were negative as well.

Her brain MRI showed abnormal signal bilaterally in the temporal lobes extending into the left insular cortex on fluid-attenuated inversion recovery sequence (figure 1) without contrast enhancement. An EEG was performed and showed nonspecific diffuse theta slowing with no epileptiform discharges or seizures.

Based on the presentation, MRI, and lumbar puncture, the differential included infectious encephalitis (i.e., herpes simplex virus-1), bilateral infarction, or toxic effect, from methamphetamine use, Hashimoto encephalopathy, or paraneoplastic/autoimmune limbic encephalitis. She was started on IV acyclovir, but her clinical course continued to decline with development of paranoid delusions by hospital day 5 .

A subsequent CT of chest, abdomen, and pelvis was normal except for subcarinal and right hilar lymphadenopathy. The patient then underwent a biopsy of a subcarinal lymph node with the final pathology consistent with a large-cell neuroendocrine carcinoma consistent with lung primary (figure 2).

The CSF paraneoplastic panel eventually returned with a positive anti-Hu antibody. Based on pathology, MRI brain, and CSF anti-Hu antibody, she was diagnosed with an anti-Hu-associated paraneoplastic limbic encephalitis with primary large-cell neuroendocrine carcinoma of the lung. She was treated with 5 days 
of plasma exchange with IV methylprednisolone without improvement in her mental status and then received 1 cycle of carboplatin and etoposide for her carcinoma. She showed no improvement over the following months and was eventually transferred to hospice care.

Large-cell neuroendocrine carcinoma of the lung (LCNEC) is histochemically similar to neuroendocrine tumors and morphologically similar to large-cell carcinomas. ${ }^{1}$ They represent approximately $2 \%-3 \%$ of malignant pulmonary neoplasms and generally have a poorer stage-for-stage survival with treatment than other non-small-cell lung cancers. The mean age of patients with LCNEC ranges from 62 to 68 years and smoking appears to be a significant risk for development of LCNEC. ${ }^{1}$

Large-cell neuroendocrine carcinoma of the lung has been associated with several paraneoplastic syndromes. These include a paraneoplastic retinopathy, ${ }^{2}$ voltage-gated calcium channel antibody-mediated Lambert-Eaton syndrome, ${ }^{3}$ and an anti-Hu-positive syndrome with painful sensory neuropathy, autonomic dysfunction, and tonic pupils. ${ }^{4}$ LCNEC is rarely associated with anti-Huassociated limb encephalitis. In one series of $167 \mathrm{pa}$ tients with anti-Hu-associated encephalomyelitis, only $4(2.4 \%)$ had primary neuroendocrine carcinoma of the lung. ${ }^{5}$ The most common cause in the same study was small-cell lung cancer with 111 (66\%) cases.

The typical evaluation for a suspected paraneoplastic limbic encephalitis includes serum and CSF paraneoplastic antibodies; MRI of the brain; CT scan of the chest, abdomen, and pelvis; and testicular ultrasound in men. CT scans alone, however, can miss small neoplasms. Recent evidence has shown that PET-CT may improve the detection rate of cancer in patients with a paraneoplastic disorder when more standard evaluations are negative. ${ }^{6}$

This case illustrates a common clinical presentation and MRI brain of a paraneoplastic limbic encephalitis. What is uncommon is the underlying primary malignancy and demonstrates that largecell neuroendocrine tumors should be considered in the differential of anti-Hu-associated limbic encephalitis.

Matthew S. West, MD, Christy Young Barbee, MD

From the Department of Neurology (M.S.W.), University of Colorado School of Medicine, Aurora; and Kaiser Permanente (C.Y.B.), Rock Creek, CO.

Disclosure: Dr. West receives a Neuroimmunology Fellowship currently sponsored by Biogen Idec. Dr. Young Barbee is an employee of Kaiser Permanente.

Address correspondence and reprint requests to Dr. Matthew S. West, University of Colorado, Denver, Research Complex 2, Mail Stop B182, 12700 E. 19th Ave, Room 5019, Aurora, CO 80045; Matthew.West@ucdenver.edu

Received August 5, 2010. Accepted in final form September 2, 2010.

1. Fernandez FG, Battafarano RJ. Large-cell neuroendocrine carcinoma of the lung. Cancer Control 2006;13: $270-275$.

2. Stanford MR, Edelsten CE, Hughes JD, et al. Paraneoplastic retinopathy in association with large cell neuroendocrine carcinoma. Br J Ophthalmology 1995;79: 617-618.

3. Di Fabio R, Benedetti L, Michailidis K, et al. Paraneoplastic neuromuscular disease in lung large cell neuroendocrine carcinoma. Can J Neurol Sci 2008;35:516-518.

4. Gordon WC, Leach M. Lung carcinoma with anti-Hu paraneoplastic syndrome. N Engl J Med 2006;355:e4.

5. Graus F, Keime-Guibert F, Rene R, et al. Anti-Huassociated paraneoplastic encephalomyelitis. Brain 2001; 124:1138-1148.

6. McKeon A, Apiwattanakul M, Lachance D, et al. Positron emission tomography-computed tomography in paraneoplastic neurologic disorders. Arch Neurol 2010;67:322-329. 


\section{Neurology}

\section{A case of confusion and bilateral temporal lesions in a young woman \\ Matthew S. West and Christy Young Barbee \\ Neurology 2010;75;S67-S68 \\ DOI 10.1212/WNL.0b013e3181fb364c}

\section{This information is current as of November 1,2010}

\section{Updated Information \&} Services

References

Subspecialty Collections

Permissions \& Licensing

Reprints including high resolution figures, can be found at: http://n.neurology.org/content/75/18_Supplement_1/S67.full

This article cites 6 articles, 1 of which you can access for free at: http://n.neurology.org/content/75/18_Supplement_1/S67.full\#ref-list-1

This article, along with others on similar topics, appears in the following collection(s):

\section{MRI}

http://n.neurology.org/cgi/collection/mri

Paraneoplastic syndrome

http://n.neurology.org/cgi/collection/paraneoplastic_syndrome

Information about reproducing this article in parts (figures,tables) or in its entirety can be found online at:

http://www.neurology.org/about/about_the_journal\#permissions

Information about ordering reprints can be found online:

http://n.neurology.org/subscribers/advertise

Neurology ${ }^{\circledR}$ is the official journal of the American Academy of Neurology. Published continuously since 1951, it is now a weekly with 48 issues per year. Copyright Copyright $@ 2010$ by AAN Enterprises, Inc.. All rights reserved. Print ISSN: 0028-3878. Online ISSN: 1526-632X.

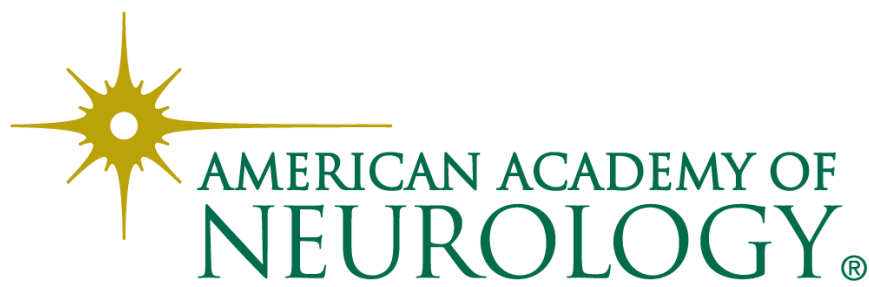

